mgr inz. Grzegorz Siewiera

\title{
Eliminacja wąskich gardeł na liniach kolejowych
}

(Materiat do artykutu przedstawiono $w$ formie prezentacji na Międzynarodowych Targach Poznańskich - Transporta 2009 - Transport Szynowy XXI wieku dla Polski.)

Koleje w Polsce po 1945r. posiadały dominującą rolę $w$ przewozie pasażerów

i towarów. W okresach szczytowych przewożono blisko $1300 \mathrm{mln}$ pasażerów oraz blisko $500 \mathrm{mln}$ ton ładunków rocznie. Zmiany społeczno-gospodarcze jak również gwałtowny wzrost ilości środków transportu drogowego spowodowały znaczne zmniejszenie przewozów drogą żelazną. Przewozy pasażerskie zmalały do 790 mln pasażerów w 1990r. i do $265 \mathrm{mln}$ w roku 2006. Przewozy towarowe zmalały

do $282 \mathrm{mln}$ ton w 1990 roku i do $142 \mathrm{mln}$ ton w 2008 roku.

W wyniku spadku przewozów, a tym samym przychodów oraz niewystarczają-

-cych źródeł finansowania od 1990 roku systematycznie pogarszał się stan infrastruktury kolejowej. Zmniejszenie długości eksploatowanych linii o $22 \%$ nie było adekwatne do zmniejszenia przewozów. Prędkości obowiązujące na eksploatowanych liniach ulegały stopniowemu zmniejszaniu. Na przykład w latach $2001 \div 2006$ prędkość zmniejszono na 13151 $\mathrm{km}$ toru, a zwiększono tylko na $4476 \mathrm{~km}$ toru.
Przyczynami tego zjawiska jest między innymi:

- starzenie się wszystkich elementów infrastruktury wskutek drastycznego ograniczenia ilości napraw

- duża ilość torów ułożonych na podkładach drewnianych, które znacznie przekroczyły nominalny okres eksploatacji

- zły stan obiektów inżynieryjnych

- duża ilość jednopoziomowych skrzyżowań z drogami kołowymi bez odpowiedniej sygnalizacji

- niewystarczający zakres inwestycji w tych elementach

Sytuacja ta zaistniała $\mathrm{z}$ powodu wieloletniego braku wystarczających środków finansowych na utrzymanie i modernizację infrastruktury kolejowej. Prowadzone inwestycje przy wykorzystaniu kredytów EBOR, EBI z uwagi na szczupłość środków nie pozwalały na kompleksową modernizację całych ciagów przewozowych łącznie ze stacjami węzłowymi, jak również na budowę nowych systemów sterowania i zarządzania ruchem kolejowym. Stąd na wielu liniach powstały 
tzw. „wąskie gardła”

tj. miejsca, gdzie parametry techniczne odbiegały od parametrów obowiązujących

na całej linii.

Dla poprawy istniejącego stanu został przygotowany wniosek do Komisji Europejskiej o przyznanie środków finansowych na realizację projektu „Poprawa stanu infrastruktury kolejowej w Polsce". Projekt likwidacji „wąskich gardel” przewidywał wykonanie prac przede wszystkim na liniach wzdłuż paneuropejskich korytarzy oraz na liniach sieci AGC i AGTC.

W zakresie prac przewidziano:

- Roboty torowe: wymiana szyn OC wymiana nawierzchni torowej wymiana rozjazdów

- Naprawa podtorza

- Naprawa obiektów inżynieryjnych

- Wymiana sieci trakcyjnej

- Zabudowa samoczynnej sygnalizacji przejazdowej

Całe zadanie zostało podzielone na pięć projektów oraz wydzielono inne prace:

Projekt 1 obejmował Korytarz III, linia E30 z odgałęzieniami

Projekt 2 obejmował Korytarz VI, linia E65, CE65

Projekt 3 obejmował łącznik pomiędzy Korytarzem II i Korytarzem III, linia E59, CE59

Projekt 4 obejmował Korytarz II, linia E20, CE59, połączenie Korytarza II i Korytarza VI linia nr 353

Projekt 5 obejmował instalację samoczynnej sygnalizacji przejazdowej na niektórych przejazdach w Korytarzach III i VI

Inne prace - elementy wyłączone z pięciu projektów.
Roboty budowlane przewidziano na następujących liniach kolejowych:

Nr 1 Warszawa-Katowice

$\mathrm{Nr} 3$ Warszawa - Kunowice - granica państwa

Nr 8 Warszawa-Kraków

$\mathrm{Nr} 91$ Kraków - Medyka

Nr 131 Chorzów Batory - Tczew

Nr 139 Katowice - Zwardoń

Nr 271 Wrocław - Poznań

Nr 273 Wrocław - Szczecin

Nr 353 Poznań Wsch. - Skandawa

Zakres rzeczowy robót realizowanych na tych liniach objął:

- wymianę nawierzchni kolejowej $314 \mathrm{~km}$

- wymianę szyn OC

$23,2 \mathrm{~km}$

- naprawę podtorza

- wymianę sieci trakcyjnej

- naprawę obiektów inżynieryjnych

$43,3 \mathrm{~km}$

- wymianę rozjazdów

- instalację s.s.p.

$27 \mathrm{szt}$.

47 szt.

17 szt.

Prace obejmują 122 lokalizacje $\mathrm{w}$ ramach rozstrzygniętych postępowań przetargowych. Termin zakończenia wszystkich prac z rozliczeniem: 31. 12. 2009r.

Efektem wykonania robót (z których większość została już zrealizowana) będzie:

- poprawa połączeń kolejowych w kierunkach północno-południowym i wschodnio-zachodnim

- zachowanie parametrów obowiązujących w korytarzach transportowych

- poprawa niezawodności i bezpieczeństwa ruchu kolejowego

- likwidacja 111 lokalizacji ograniczeń prędkości

- skrócenie czasu przejazdu pociągów pasażerskich łącznie o 204 minuty

Finansowanie projektu: Fundusz Spójności $75 \%$, budżet państwa $25 \%$

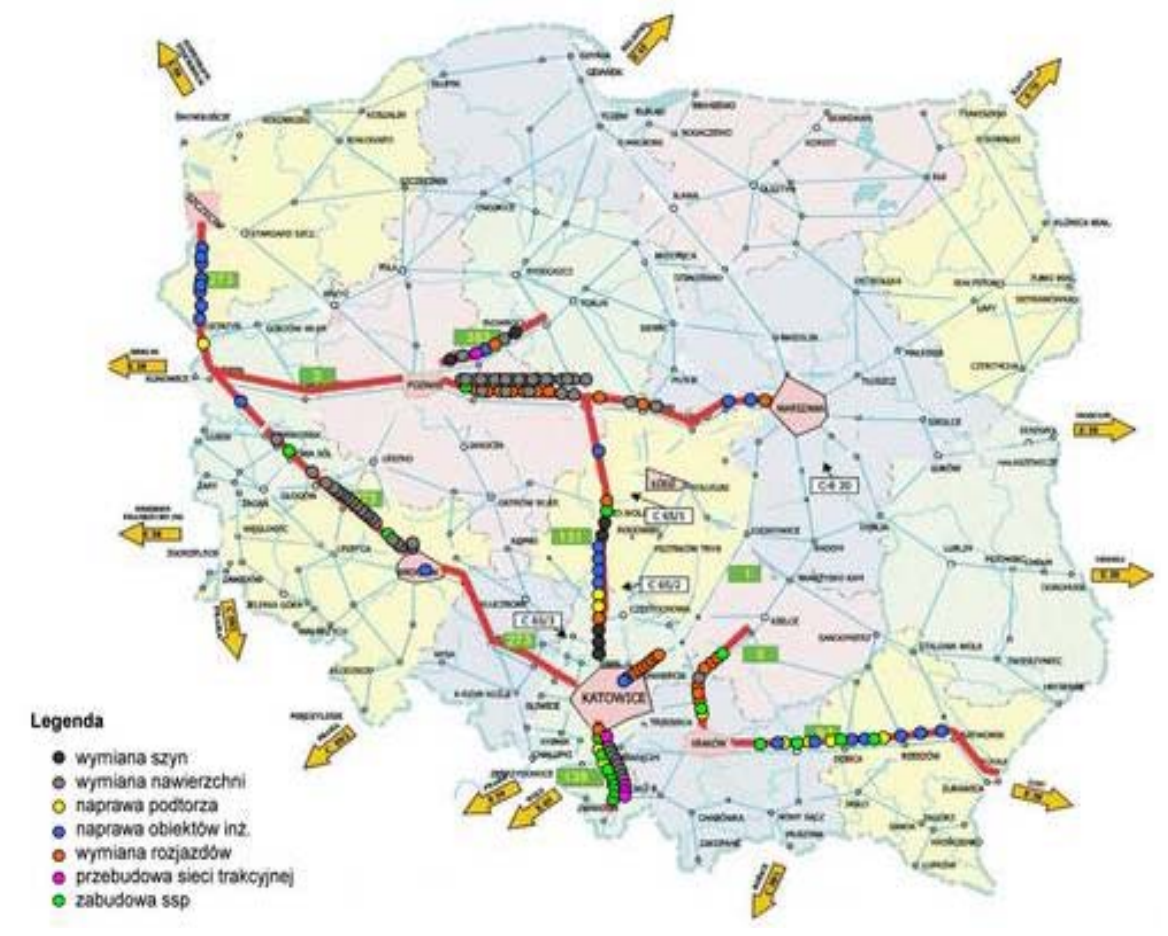

$W$ opracowaniu wykorzystano upublicznione informacje Ministerstwa Infrastruktury i PKP PLK S.A. 